\title{
Interpretation of the Paradoxical Relations in Teaching of Business English Writing
}

\author{
Le Guobin \\ School of Foreign Languages, Huaihua University \\ Hunan Province, P. R. China 418008 \\ 2290401869@qq.com
}

\begin{abstract}
As an ESP, Business English is strongly characterized by practicality and professionalism. English output abilities, that is, oral and written expression abilities, are key indicators of the success of business English teaching. The outcome of business English writing lessons is closely related to the following four aspects: content of teaching, teaching methods, selection of textbooks, and methods of assessment. By analyzing and clarifying the paradoxical relations in the above four aspects, teachers and researchers can better achieve desired teaching results and eventually help students enhance their business English writing abilities.
\end{abstract}

Keywords-Business English writing; Teaching process; Paradoxical relations

\section{INTRODUCTION}

Listening, Speaking, Reading, Writing and Translating skills have long been prioritized in foreign language teaching. As one of the major output skills, the importance of writing skills is self-evident. As an ESP, business English is all the more prominent in terms of practicality and professionalism and thus business English majors' writing ability can be considered the epitome of such practicality and professionalism.

Since the 1960s, researchers have broken through the traditional product approach and subsequently proposed the process approach (in the 1970s), the genre-based approach (in the 1980s), the content-based approach (in the 1980s), and the task-based approach (in the 1980s). As the above approaches to the teaching of writing subjects have their respective advantages and disadvantages, discussions in this field of teaching writing subjects have continued, only in a deepening context.

In 2006, the Ministry of Education approved the pilot program of Business English in the University of Foreign Economics and Trade, and in 2012, the major of Business English was formally listed by the Ministry of Education. As a new major under the category of foreign language and literature, related teaching and research still needs to be further promoted. Business English major was born because of the development of China's international commercial trade. Almost all international business activities need to be supported and evidenced by written English, so writing as an important export skill of business English deserves special attention
Since the establishment of Business English as a pilot program in 2006, the research on business English writing has greatly increased both in theory and in practice. A search for Business English Writing in China shows that the number of research papers on Business English writing has exceeded 100 since 2008, totaling over 200 in 2012, and has been stable at about 140-150 in the following years. By combing the papers about Business English writing published online in China, we can find that the papers on Business English writing mainly focus on the following three aspects: (1) Business English writing skill training, such as Fu Meirong (2000)[1], Dai Dongdong (2001)[2], Chen Xiaoxiao and Ge Shili (2016)[3]; (2) Business English writing textbook planning, such as Mo Zaishu and Sun Wenjuan (2010)[4], Tan Dinghua (2014)[5]; (3) Business English writing's teaching modes, such as Wang Jing (2009)[6], Liu Jingrong (2013)[7], Xie Hua (2014)[8], Le Guobin (2017)[9].

No matter how the teaching method changes, no matter how the teaching content or teaching material is updated, it has always been the goal to effectively improve students' writing ability of Business English and the direction and standard of Business English writing teaching. However, in the process of moving toward the goal, the following four kinds of contradictory relations need to be clarified for a better understanding and implementation of the teaching of Business English writing subjects.

\section{CONTRADICTION IN THE CONTENT OF TEACHING WRITING SUBJECTS: ENGLISH KNOWLEDGE VS. BUSINESS KNOW-HOW}

Whether the writing class is a skill-based course or an ideological content training course has been controversial in the field of foreign language teaching. Many Business English writing textbooks teach students how to make sentences, how to straighten out syntax, how to organize paragraphs, and how to link paragraphs into articles. However, less attention has been paid to the necessary ideological content of writing, including how to enlarge Business English vocabulary to improve students' expressive ability, and how to use Business English knowledge to solve business problems. As a result, when students write Business English compositions, their language expression is monotonous and their ideological content is empty. 
Whether it is the product approach that prevailed before the 1960 s or the later process approach and the genre-based approach, the writing classroom has paid too much attention to the form of an article than to the content and viewpoint of the article. This problem has been improved in content teaching method and task teaching method, but the importance of writing content is still less than that of language expression. The birth of Business English is the inevitable result of the development of China's international business trade. Therefore it is inevitable for Business English writing to serve business and trade, and for the activities and tasks in business and trade to become the core content of writing.

For business English writing ability, students' English knowledge and business knowledge are both indispensable. Without English knowledge, business knowledge will lose the carrier; without business knowledge, business English writing will have no purpose. For basic writings of business English, the textbook A Basic Course of English Writing, which has long been regarded as the standard, emphasizes the basic skills of English writing [10], including punctuation, word choice, sentence formation, paragraph writing, text writing, and so on. This classic textbook has been updated in many editions and has been used by colleges and universities all over the country. But without the input of Business English knowledge, the writing knowledge and skills taught in the basic course of English Writing will be of little avail. In the case of meeting notification writing, no company's formal meeting notification will follow the paradigm suggested in the above-mentioned textbook, let alone business or industry conference notifications. It is obvious that without business knowledge, English knowledge in the teaching of business English writing will be pointless. On the other hand, without sufficient knowledge of English, business English knowledge in the teaching of business English writing will may not be properly substantiated.

\section{CONTRADICTION IN TEACHING METHODS FOR BUSINESS ENGLISH WRITING: TEMPLATIZATION VS. PERSONALIZATION}

Before the 1960s, the product approach occupied a dominant position in the field of English teaching. Luo Mingli [11] argues that writing is closely related to language knowledge, and the emphasis of the teaching of writing subjects lies in mastering the relevant lexical, syntactic and textual cohesive devices. In the classroom featuring the product approach, the teacher is in the dominant position, emphasizes the teaching writing knowledge and the writing skill, and pays attention to the correctness of the language and the structure and the quality of the article. The teacher first guides the students to analyze the model text and explains it, then the students imitate the model essay and write, then the teacher evaluates and grades the compositions, and finally the students revise the article according to the teacher's comments. Thus, the whole process of students' writing is completed under the teacher's control, and they can not demonstrate their respective personalities. Writing becomes a kind of mechanical imitation and editing activities, and the students' written communication ability is not fully trained. On the one hand, the teacher spends a lot of time and energy correcting compositions, while the students usually only care about the assessment grades and/or the scores, and ignore the teacher's comments and amendments, which eventually leads to similar mistakes in future writings. On the other hand, teachers can only give students comments and suggestions based on the results of writing, pay attention to the form of language expression, ignore the content and point of view of writing, without understanding the difficulties encountered by the students in the process of writing. The result is that the students' English output ability has not effectively improved.

In view of the disadvantages of the product approach, researchers have been exploring other approaches and put forward the process approach (in the 1970s), the genre-based approach (in the 1980s), the content-based approach (in the 1980s), and the task-based approach (in the 1980s). Li Jinhong [12].

From the product approach to the process approach and to the genre-based approach, the trend of templatization in teaching writing subjects has not been fundamentally changed. This is because teachers need to standardize the format and assessment requirements of students' writings: the reference answer (reference article) is both a standard answer and a standard template, and any deviation from the template may be regarded as inadequate. In fact, deviations from the template are likely to be where students' personalization lies.

In order to encourage students to write in a creative and personalized manner, the task-based approach came into being. The content-based approach requires the teacher to take specific writing content as the focus and to instruct the students to make preparations before the actual writing. A key to writing lies in the preparation before the actual writing, rather than the teaching of writing skills. The task-based approach also requires teachers to arrange various forms of writing tasks according to their specific writing purposes, students' language proficiency and different content themes, so as to enable students to write in the target language in the process of completing the tasks. However, it needs to be pointed out that without the knowledge of business module, the content-based approach will also lose its effects.

\section{CONTRADICTION IN THE CHOICE OF WRITING TEXTBOOKS: THEORETICAL VS. PRACTICAL; COMPREHENSIVE VS. PROFESSIONAL}

Teaching materials are one of the indispensable tools in teaching, and Business English writing textbooks are no exception. The impact of teaching materials on teaching effects can not be ignored, especially for new teachers. Xia Jimei (2001) [13] holds that modern foreign language textbooks have become the basis or tool of communication, rather than "language models" or "language knowledge textbooks" in the traditional sense; they are people-oriented, task-oriented and communicative.

There are a wide range of writing textbooks available for business English majors, including dozens of mainstream textbooks. Most of the basic business English writing textbooks teach students how to make sentences, how to straighten out syntax, how to organize paragraphs, and how to link paragraphs into an article. Professional business English 
writing textbooks usually focus on how to enrich business English vocabulary in order to improve their ability of expression, how to use business English knowledge to solve business problems and so on.

It is true that Business English is more practical, but practicality alone is not enough; it should also be theoretical and can guide the writing of commercial English letters and other writings. Zong Baolin (1983) [14] pointed out one of the teaching materials for foreign trade correspondence. The serious deficiency lies in the lack of theoretical exposition. Mo Zaishu et al (2010) [15] collected and analyzed 490 kinds of business English writing textbooks since 1958. One of the general characteristics of the English writing materials in China is that one of the main characteristics of the English writing textbooks is that there are many imitations of Western theories, resulting in a lack of theory and principles for the compilation of textbooks and a lack of a theoretical framework as the core of the system. Mo Zaishu believes that the above business writing textbooks are less concerned with relevant linguistic theories, foreign language teaching theories, the ideas and principles of textbook compilation and business communication theory, and have paid less attention to the business writing process, social cultural factors, writing teaching, and so on.

The main theoretical source of language teaching is linguistic theory, specifically applied linguistics or language acquisition theory. The theory of business English writing textbooks has been criticized for many years, and one of the main reasons is that Business English writing is more practical and professional than ordinary English writing. Fortunately, in recent years, editors of business English writing textbooks have begun to attach importance to the interlingual communicative function of Business English writing. Since 2000, some Business English writing textbooks have begun to pay attention to the social pragmatic aspects of discourse. Some textbooks have begun to discuss the motivation of the language forms used in business activities and pragmatic strategies of business communication, such as Wang Yongxiang (2009)[16], who advocates that the teaching of business English writing should "aim at developing the communicative competence of business English" in his textbook A Coursebook for Business English Writing.

\section{CONTRADICTION IN ASSESSING Writings: FoRMATIVE VS. SUMMATIVE}

Assessment includes all testing and evaluation activities during the teaching process. In terms of time and function, evaluations are usually divided into formative Assessment and summative Assessment. Formative assessment is concerned with students' performance, achievements, learning attitude and learning strategies in the process of learning. Summative assessment is concerned with the teaching effect after a period of studies. Unlike formative assessment, summative assessment usually takes a fixed form, such as midterm and final exams. In short, students will make preparations for a fixed period of time to complete a set of questions. From the above comparative analysis we may come to the conclusion that formative assessment is more conducive to promoting the development of students' writing strategies.
As early as 2000 years ago, Confucius proposed "teaching according to a student's aptitude", that is, teaching according to the students' specific conditions. That is to say, the teacher helps students find their own learning methods and help them find their own strengths and weaknesses in the process of learning, thus fundamentally arousing students' enthusiasm for learning. Ultimately, it helps students achieve holistic development in their studies. It is not difficult to understand that formative assessment is in essence more in line with Confucius' teaching idea of "teaching according to a student's aptitude". However, the implementation of formative assessment is not easy for the teaching of business English writing in that it is almost impossible for students to practice writing throughout the writing class, and that it is difficult for teachers to assess all the students' writing process on the spot.

The feasible teaching mode for the writing class is that the teacher explains writing skills in class, students practice writing after class, and then the teacher assesses the writing and gives feedback. However, most students do not study the comments carefully; they only pay attention to the grades or grades. As a result, formative evaluation will be of little effect and in fact give way to summative assessment.

How to combine formative assessment with summative assessment is the key to help with the teaching of Business English writing subjects. In view of the characteristics of these two kinds of assessment, more and more researchers have started to explore new assessment models, such as Zhang Xiaodan (2009)[17], Wang Xuefeng (2011)[18], Tan Boxun (2015)[19] and so on. Synthesizing the existing research, this article holds that the assessment of the teaching of business English subjects can be carried out in the following mode: taking the final examination as the summative assessment and taking into account the formative assessment in the teaching process, the comprehensive assessment results of the students are finally given. On the basis of the task-based approach and the genre-based approach, the teachers can choose schematic structures of specific business discourse genre to explain to students how to write articles of this genre. Students save each step of writing achievement by themselves and gradually discover and overcome the problems and shortcomings in writing. Meanwhile, the teacher can give the students a diachronic evaluation based on their writing process, way of thinking and speed of writing with a view to helping students to develop their own styles of writing.

\section{CONCLUSION}

Business English writing not only has the basic requirements of ordinary English writing, but also has its own writing characteristics, writing forms and writing methods. In addition to basic language skills such as vocabulary and grammar, business English also attaches importance to the use of language in the process of business activities. Therefore due attention should be paid to the application of students' practical writing ability in learning business English writing. In order to achieve better teaching results, teachers and researchers of Business English writing should actively and effectively grasp and deal with the contradictory relations between content for writing, teaching model, teaching material selection and assessment, sublate the traditional writing teaching mode, and 
further expand the framework for the development of business English writing ability by combining basic writing skills and business knowledge.

\section{REFERENCES}

[1] Fu Meirong. LCCI Business English Writing Standard and Business English letter Writing skills [J]. Foreign language teaching, 2000(1):3135.

[2] Dai Dongdong. On Business English Writing [J]. Journal of Northeast University (Social Sciences Edition), 2001(3):221-223.

[3] Chen Xiaoxiao, Ge Shili. An Exploration of Business English Writing Ability from the Perspective of Business Communication [J]. Foreign language Research, 2016(2):58-62.

[4] [4][15] Mo Zaishu, Sun Wenjuan. A study on the Construction of Business English Writing Textbooks [J]. Foreign language teaching, 2010(9):81-85.

[5] Tan Dinghua. A study on the Writing System of Business English Writing Textbooks from the Perspective of Genre [J]. Journal of Inner Mongolia Normal University (Educational Science Edition), 2014(8):7981.

[6] Wang Jing. The Teaching Model of Business English Writing Based on Memetics [J]. Journal of Changchun University of Technology (Social Sciences Edition), 2009(1):149-150.

[7] Liu Jingrong. An Approach to Case-based Teaching Model of Business English Writing, Chinese University Teaching, 2013(3):43-45.

[8] Xie Hua. Application of CBI Teaching Model in Business English Writing Teaching $[\mathrm{J}]$. Journal of Hunan University of Commerce, 2014(3):126-128.

[9] Le Guobin. A Probe into the Model of Developing the Applied Writing ability of Business English Majors [J]. Examination and Evaluation (College English Teaching and Research Edition), 2017(2):3-6.

[10] Ding Wangdao. A Basic Course of English Writing [M]. Beijing: Higher Education Press, 2010.

[11] Luo Mingli. A Review of Foreign Language Writing Teaching Methods [J]. Foreign Theoretical Trends, 2008 (11): $96-99$.

[12] Li Jinhong. Enlightenment of Mainstream Foreign Writing Theories to the Teaching of Foreign Language Writing in China [J]. Foreign Language Teaching, 2006(2):41-46.

[13] Xia Jimei. Characteristics and Significance of Modern Foreign Language Textbooks [J]. Foreign Language World, 2001(5):37-40.

[14] Zong Baolin. Comments on "English Correspondence in Foreign Trade"[J]. Issues in International Trade, 1983 (4) :56-59.

[15] Wang Yongxiang. A Coursebook in Business English Writing [M]. Beijing: Machinery Industry Press, 2009.

[16] Zhang Xiaodan. Formative Assessment Promoting the Cultivation of English Writing Strategies [J]. Journal of Shenyang Normal University (Social Science Edition), 2009(1):155-157.

[17] Wang Xuefeng. Formative Assessment's Feedback Cycle and Assessing Principles and

[18] Measures for the Teaching of English Writing [J]. Journal of PLA Foreign languages Institute, 2011(1):52-55.

[19] Tan Boxun. An Analysis of the Formative Assessment-oriented Higher Vocational Curriculum Assessment Model: Taking the Reform of Applied Writing Curriculum Assessment Scheme as an Example [J]. Journal of Guangxi Economic Management Cadre Institute, 2015(4):97102 . 